\title{
Pulmonary aspergillus infection invading the pleura
}

\author{
GUNNAR HILLERDAL
}

\author{
From the Department of Pulmonary Medicine, University Hospital, Uppsala, Sweden
}

ABSTRACT During a 10-year-period, six patients with non-postoperative aspergillus infection of the pleura were seen. In all patients a pulmonary aspergillus infection had been present for some years. The fungus invaded the pleura, causing a bronchopleural fistula and a cavity in the pleural space. A prerequisite for the pleural aspergillosis was that the lung and pleura were previously damaged, usually by therapeutic pneumothorax for active tuberculosis some decades earlier. The fungus can cause destruction of the lung and death of the patient from the chronic infection unless treated. The best treatment is early excision of the pleura with resection of the upper lobe or if necessary the whole lung. To reduce the risk of postoperative aspergillus empyema, the patient should be treated with antifungal agents before and after operation. In inoperable patients, local antifungal treatment may clear the infection but is not always effective.

Aspergillus infection of a previously damaged lung is not uncommon. This fungus is usually regarded as saprophytic, of importance mainly because of occasional allergic reactions or haemoptyses. Only in immunocompromised patients has it been considered to be invasive. Pleural infection by aspergillus is regarded as a superinfection of a preformed cavity in the pleura or a post-operative complication. However, the fungus can be invasive in a fibrotic pleura in a non-immunocompromised host, as seen from the following cases.

\section{Patients}

From 1969 to 1979, six patients with non-postoperative pleural aspergillosis have been diagnosed. Five of them were treated with pneumothorax for active tuberculosis some decades earlier, leaving a fibrosed pleura, in some cases with calcification but without any cavities or remarkable thickening (table 1). At least two patients (cases 2 and 6) had had symptoms that could be attributable to an aspergillus infection of the lung for some years before the present disease manifestations. Two had received anti-tuberculous chemotherapy despite the fact that no bacilli or signs of active tuberculosis could be found (cases 1 and 2).

All patients presented with signs and symptoms of chronic infection of some months durationnamely, loss of weight, malaise, cough, raised sedimentation rate, and anaemia.

Address for reprint requests: Dr G Hillerdal, Department of Pulmonary Medicine, University Hospital, Uppsala, Sweden.
The diagnosis of aspergillosis was established by serological tests, and by fungal growth from the pleura and in some cases also the sputum (table 2). All patients had high titres of precıpitins against Aspergillus fumigatus in their blood. Biopsies of pleura showed non-specific fibrosis and granulomas, and only when specimens from an actual mycetoma were examined could the diagnosis be made from pathological findings.

Aspergillus fumigatus was grown from the pleural fluid in all cases, but repeated samples were often necessary. In one empyema anaerobic streptococci were found twice, but otherwise no other suspect pathogens were grown. Anaerobic cultures were not performed in all cases, however, and coexistence of such bacteria is therefore possible. With the appearance of the first symptoms, all patients were treated by their general practitioners with penicillin and broad spectrum antibiotics, generally in repeated courses, without improvement, which indicates that if bacteria were present their importance was only minor.

Four patients underwent operation. Two of them recovered uneventfully. Both underwent lobectomy and decortication only, and one of them had preoperative treatment with antifungal drugs. In the other two, extension into the lung of the pleural fibrotic tissue and parenchymal destruction necessitated pneumonectomy. Both of these patients developed a postoperative empyema from which $A$ fumigatus was grown. Neither had had preoperative antifungal treatment. After intensive local treatment the empyema in one of the patients cleared and he is 
Table 1 Clinical data

\begin{tabular}{|c|c|c|c|c|c|c|c|c|c|c|}
\hline Case & $\begin{array}{l}\text { Year } \\
\text { of } \\
\text { birth }\end{array}$ & Sex & $\begin{array}{l}\text { Therapeutic } \\
\text { pneumothorax }\end{array}$ & $\begin{array}{l}\text { Symptoms } \\
\text { from fungal } \\
\text { infection }\end{array}$ & $\begin{array}{l}X \text {-ray (numbers } \\
\text { refer to figures) }\end{array}$ & $\begin{array}{l}\text { Anti- } \\
\text { tuberculous } \\
\text { treatment }\end{array}$ & $\begin{array}{l}\text { Steroid } \\
\text { treatment }\end{array}$ & $\begin{array}{l}\text { Anti- } \\
\text { fungal drugs }\end{array}$ & Operation & Course \\
\hline 1 & 1926 & $\mathbf{M}$ & $\begin{array}{l}\text { Bilateral } \\
1946-57\end{array}$ & $\begin{array}{l}\text { Jan } 1972: \\
\text { productive } \\
\text { cough } \\
\text { weight loss } \\
\text { malaise }\end{array}$ & $\begin{array}{l}\text { May to Sept } 1972: \\
\text { progressive } \\
\text { changes left } \\
\text { side (la-h) }\end{array}$ & $\begin{array}{l}\text { May } 1972 \\
\text { to } \\
\text { Aug } 1973\end{array}$ & None & None & $\begin{array}{l}\text { Upper } \\
\text { lobectomy t- } \\
\text { decortication }\end{array}$ & $\begin{array}{l}\text { Uneventfu } \\
\text { Alive, } \\
\text { respirato } \\
\text { invalid }\end{array}$ \\
\hline 2 & 1916 & $\mathrm{~F}$ & $\begin{array}{l}\text { Bilateral } \\
1936-47\end{array}$ & $\begin{array}{l}\text { Since } 1965 \\
\text { cough, } \\
\text { haemoptyses, } \\
\text { asthma. 1971: } \\
\text { weight loss, } \\
\text { fever }\end{array}$ & $\begin{array}{l}1947 \text { to } 1963 \\
\text { apical scars } \\
1963: \\
\text { progression. } \\
1971: \\
\text { pyopneumothorax } \\
(2 \text { a-d })\end{array}$ & $1963-65$ & $1965-67$ & $\begin{array}{l}\text { Local } \\
\text { amphotericin } \\
\text { B }\end{array}$ & Inoperable & $\begin{array}{l}\text { Died } 5 \text { mó } \\
\text { after firs } \\
\text { sign of of } \\
\text { in pleura }\end{array}$ \\
\hline 3 & 1896 & $\mathbf{M}$ & Left 1944 & $\begin{array}{l}1969 \text { cough, } \\
\text { fever, loss of } \\
\text { weight }\end{array}$ & $\begin{array}{l}\text { 1969: aspergilloma } \\
\text { left. } 1970: \\
\text { pyopneumothorax }\end{array}$ & $\begin{array}{l}\text { 1960-61 } \\
\text { (positive } \\
\text { sputa) }\end{array}$ & None & None & $\begin{array}{r}\text { Operation } \\
\text { declined }\end{array}$ & $\begin{array}{c}\text { Died after } \\
\text { months }\end{array}$ \\
\hline 4 & 1921 & $\mathbf{M}$ & $\begin{array}{l}\text { Right, } \\
1950-55\end{array}$ & $\begin{array}{l}\text { 1969: malaise, } \\
\text { fever, cough, } \\
\text { loss of } \\
\text { weight }\end{array}$ & $\begin{array}{l}\text { 1955-60 apical } \\
\text { scars. } 1960 \text { to } \\
\text { 1969: slow } \\
\text { progression. } \\
\text { 1969: } \\
\text { pyopneumothorax } \\
(3 \mathrm{c}-\mathrm{e})\end{array}$ & None & None & $\begin{array}{l}\text { Local }+ \\
\text { systemic } \\
\text { after } \\
\text { operation }\end{array}$ & $\begin{array}{l}\text { Decortication }+ \\
\text { pneumonectomy }\end{array}$ & $\begin{array}{l}\text { Postopera } \\
\text { empyem } \\
\text { after } 4 \\
\text { months' } \\
\text { hospital } \\
\text { treatmen } \\
\text { now in } \\
\text { good he }\end{array}$ \\
\hline 5 & 1921 & $\mathbf{M}$ & None & $\begin{array}{l}\text { Cough for } \\
\text { many years. } \\
\text { May 1979: } \\
\text { worse, } \\
\text { dyspnoea, } \\
\text { fever, loss } \\
\text { of weight }\end{array}$ & $\begin{array}{l}\text { 1978: Apical } \\
\text { scarring. May } \\
\text { 1979: } \\
\text { progression. } \\
\text { Postop } \\
\text { infiltrates other } \\
\text { side (4 a-b) }\end{array}$ & None & None & $\begin{array}{l}\text { Local }+ \\
\text { systemic } \\
\text { after } \\
\text { operation }\end{array}$ & $\begin{array}{l}\text { Decortication }+ \\
\text { pneumonectomy }\end{array}$ & $\begin{array}{l}\text { Postoperat } \\
\text { empyem } \\
\text { died of } \\
\text { aspergill } \\
\text { pneumo } \\
5 \text { month } \\
\text { after } \\
\text { operatio } \\
\text { (verified- } \\
\text { necrops }\end{array}$ \\
\hline 6 & 1918 & $\mathrm{~F}$ & $\begin{array}{l}\text { Right, } \\
\text { 1943-44 }\end{array}$ & $\begin{array}{l}\text { 1973-78 cough. } \\
\text { Dec 1978: } \\
\text { loss of } \\
\text { weight, } \\
\text { subfebrile }\end{array}$ & $\begin{array}{l}\text { Until 1973, apical } \\
\text { scarring. May } \\
\text { 1979: } \\
\text { aspergilloma and } \\
\text { pleural cavity (5) }\end{array}$ & None & None & $\begin{array}{l}\text { Systemic } 2 \\
\text { weeks before } \\
\text { and } 2 \text { weeks } \\
\text { after } \\
\text { operation }\end{array}$ & $\begin{array}{l}\text { Decortication } \\
\text { lobectomy }\end{array}$ & $\begin{array}{l}\text { Uneventfu } \\
\text { remains } \\
\text { good he }\end{array}$ \\
\hline
\end{tabular}

Table 2 Diagnosis of aspergillosis

\begin{tabular}{|c|c|c|c|c|c|}
\hline Case & $\operatorname{Ig} E$ & Precipitin titre & Fungal sputum & Growth from pleura & Pathological findings \\
\hline 1 & Negative & High & Positive & Not done & $\begin{array}{l}\text { Fibrosis with } \\
\text { granulomas }\end{array}$ \\
\hline 2 & Not done & High & Positive & Positive & Abscesses, granulomas \\
\hline $\begin{array}{l}3 \\
4\end{array}$ & $\begin{array}{l}\text { Not done } \\
\text { Negative }\end{array}$ & $\begin{array}{l}\text { High } \\
\text { High }\end{array}$ & $\begin{array}{l}\text { Negative } \\
\text { Negative }\end{array}$ & $\begin{array}{l}\text { Not done } \\
\text { Positive }\end{array}$ & $\begin{array}{l}\text { Chronic fibrosis, } \\
\text { granulomas }\end{array}$ \\
\hline 5 & Negative & High & Negative & Positive & $\begin{array}{l}\text { Necrotic areas, } \\
\text { granulomas, hyphae } \\
\text { in aspergilloma }\end{array}$ \\
\hline 6 & Negative & High & Positive & Positive & $\begin{array}{l}\text { Typical hyphae in } \\
\text { aspergilloma, } \\
\text { otherwise fibrosis }\end{array}$ \\
\hline
\end{tabular}




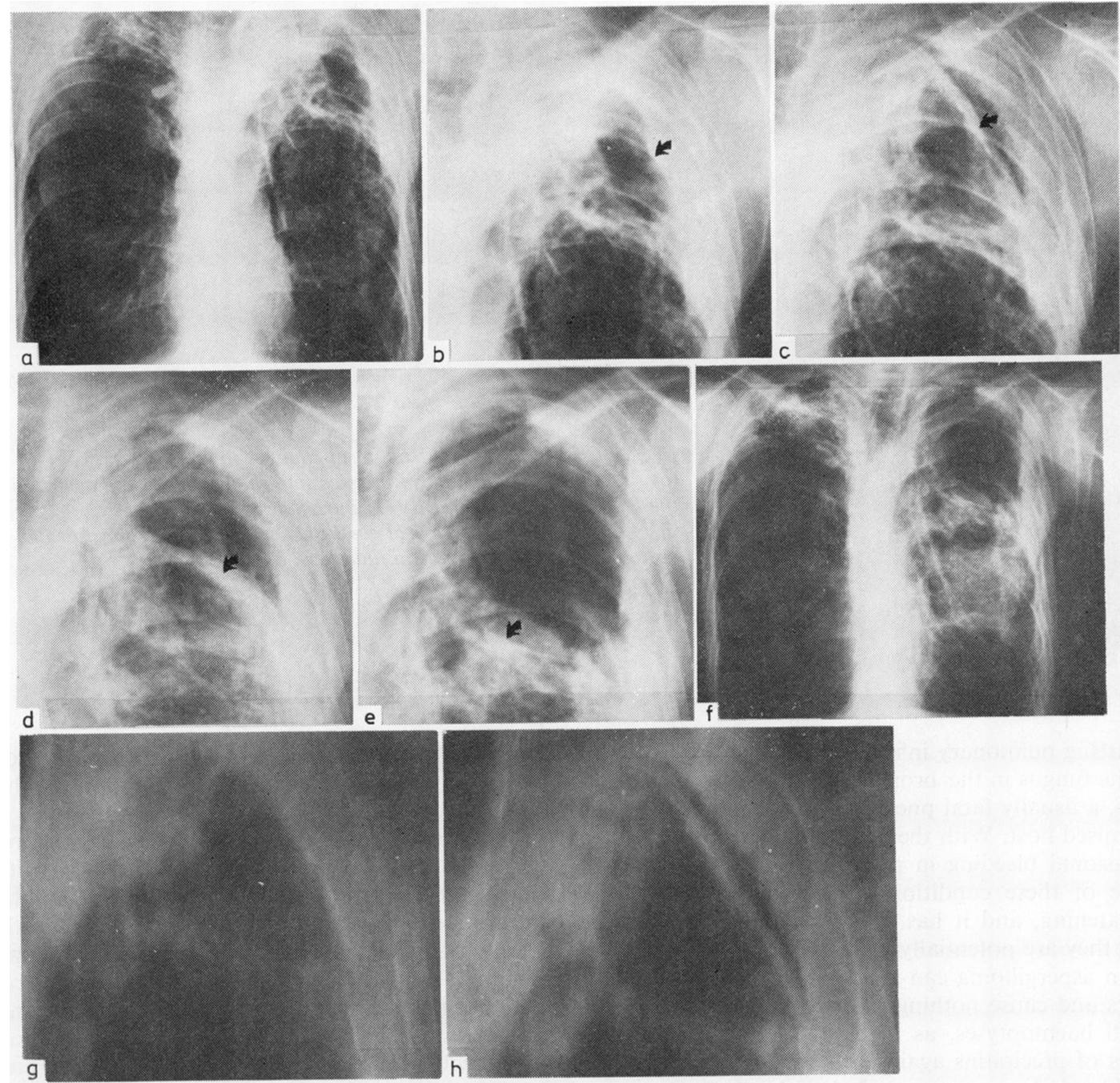

Fig 1 Case 1. (a) May 1972: apical scarring bilaterally. (b-e) development of pleural apical cavity on left side. (b) May 1972, close-up of a; (c) July; (d) September; (e) October, close-up of $f ;(f)$ The arrow points to the same small calcification within the visceral pleura. $(g)$ tomogram May; no air in the pleura. $(h)$ Tomogram July; air separating the visceral from the thickened parietal pleura.

now well, but in the other the empyema persisted and the patient died of aspergillus pneumonia in the remaining lung despite systemic and local antifungal treatment.

Two patients were not operated on. Both succumbed to their infection, one of them despite local antifungal treatment.

\section{Discussion}

Aspergillus infection of the lung is not uncommon among patients attending a chest department. ${ }^{12}$ Three clinical types are usually described: aspergilloma - that is, a fungus ball within a cavity; allergic bronchopulmonary aspergillosis, with eosinophilia, 

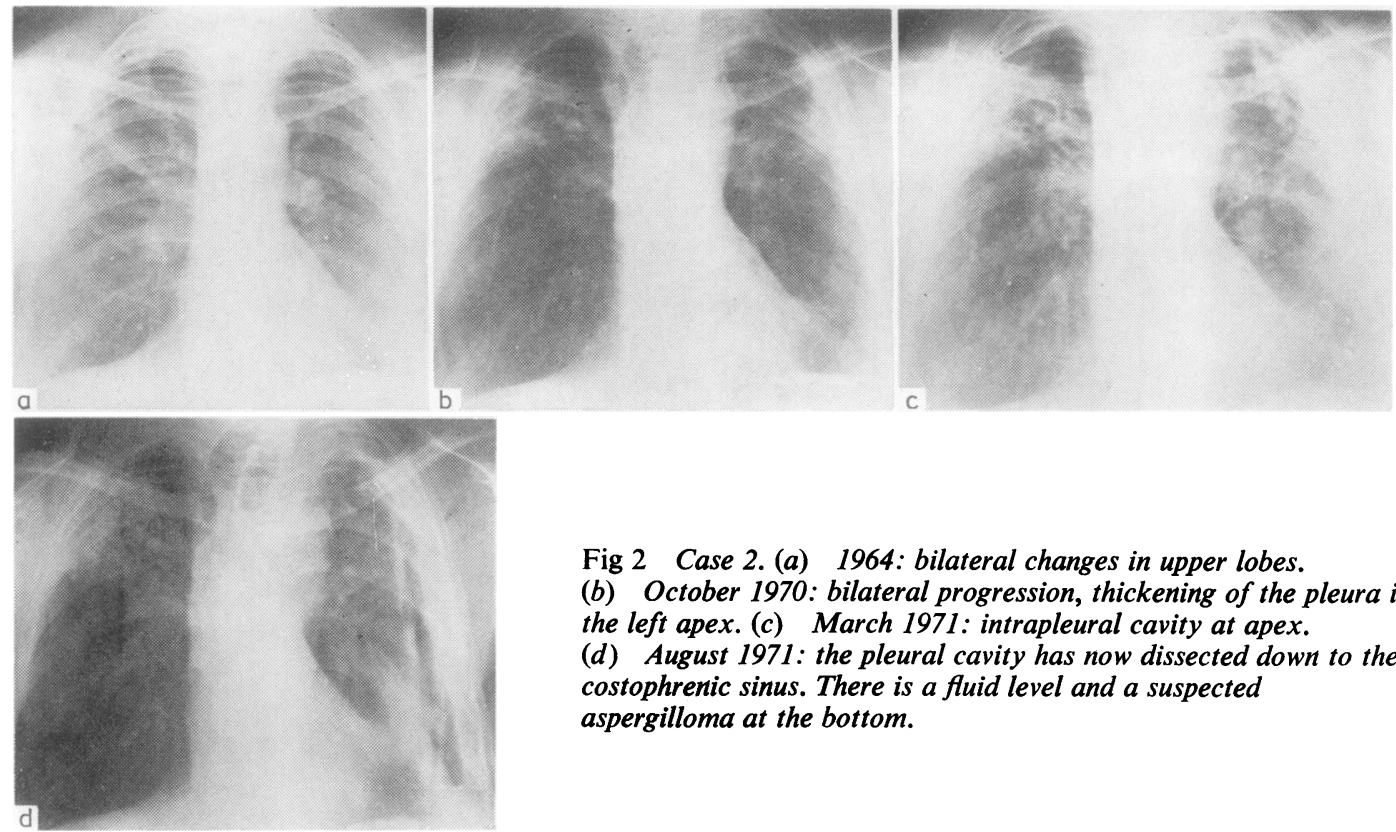

Fig 2 Case 2. (a) 1964: bilateral changes in upper lobes. (b) October 1970: bilateral progression, thickening of the pleura in the left apex. (c) March 1971: intrapleural cavity at apex.

(d) August 1971: the pleural cavity has now dissected down to the costophrenic sinus. There is a fluid level and a suspected aspergilloma at the bottom.

recurring pulmonary infiltrates, asthma, and growth $o f$ the fungus in the bronchi; and invasive aspergillosis, a usually fatal pneumonia in an immunocompromised host. With the exception of the latter, and occasional bleeding in patients with aspergillomas, none of these conditions is considered to be life threatening, and it has only recently been realised that they are potentially progressive. ${ }^{3}$

An aspergilloma can reside in the lung for many years and cause nothing more than slight cough or small haemoptyses, as in cases 2, 5, and 6. High titres of precipitins against the fungus are found in the blood. As seen in cases 2, 4, and 6, the fungus can be locally destructive in a previously damaged lung and form a cavity. This usually takes place at the apices, and the radiographic changes will often be interpreted as reactivation of tuberculosis. ${ }^{1}$ Cases 1 and 2 are good examples of this. It has been stated that antituberculous drugs increase the risk of aspergillus infection. This idea may possibly result from a diagnosis of the real cause of the changes some time after the wrong treatment (that is, antituberculous drugs) has been given.

A typical sign of aspergillus growth in a lung cavity is thickening of the pleura overlying it. ${ }^{45}$ It is unclear whether this is caused by actual fungal growth or by an immunological reaction. ${ }^{4}$ Since the precipitins remain high, a constant challenge by the fungus must take place-most probably by growth in the "capsule". In the cases described here the spread of the pleural thickening down to the costophrenic angle before cavitation strongly supports the growth theory.

There is an intense reaction to the fungus, making it virtually impossible for the pathologist to identify it in the thick fibrotic tissue. If the defences of the host are not adequate for some reason, the fibrotic tissue will spread and then break down, emptying through a bronchopleural fistula. Once a pleural cavity has formed, it will grow, causing collapse and destruction of the lung. An aspergilloma can develop in the cavity. The parietal pleura becomes thick and nodular, "pseudomesotheliomatous", ${ }^{6-8}$ as seen in figs $1,2 \mathrm{c}$-d, 3 c-e.

Unless the development is closely followed radiologically, it is difficult to judge in the final stage, either at operation or autopsy, whether the or cavity is parenchymal or pleural. For example, in $N$ 1977 a case report showed a mycetoma migrating from the top to the bottom of the lung, presumably as a result of lung destruction by coexistent tuberculosis. ${ }^{9}$ This was more likely invasive pleural aspergillosis. It is not merely an academic question, since the $\stackrel{0}{\rightarrow}$ treatment is different if the fungus is regarded as the main pathogen.

Fever, malaise, and a high sedimentation rate in $\mathbb{D}$ mycetoma patients were described in $1970 .{ }^{10}$ In the $\overparen{\mathbb{D}}$ published illustrations considerable pleural thickening can be seen, and cure was by pneumonectomy. Thus, the findings can be explained by fungal in- 

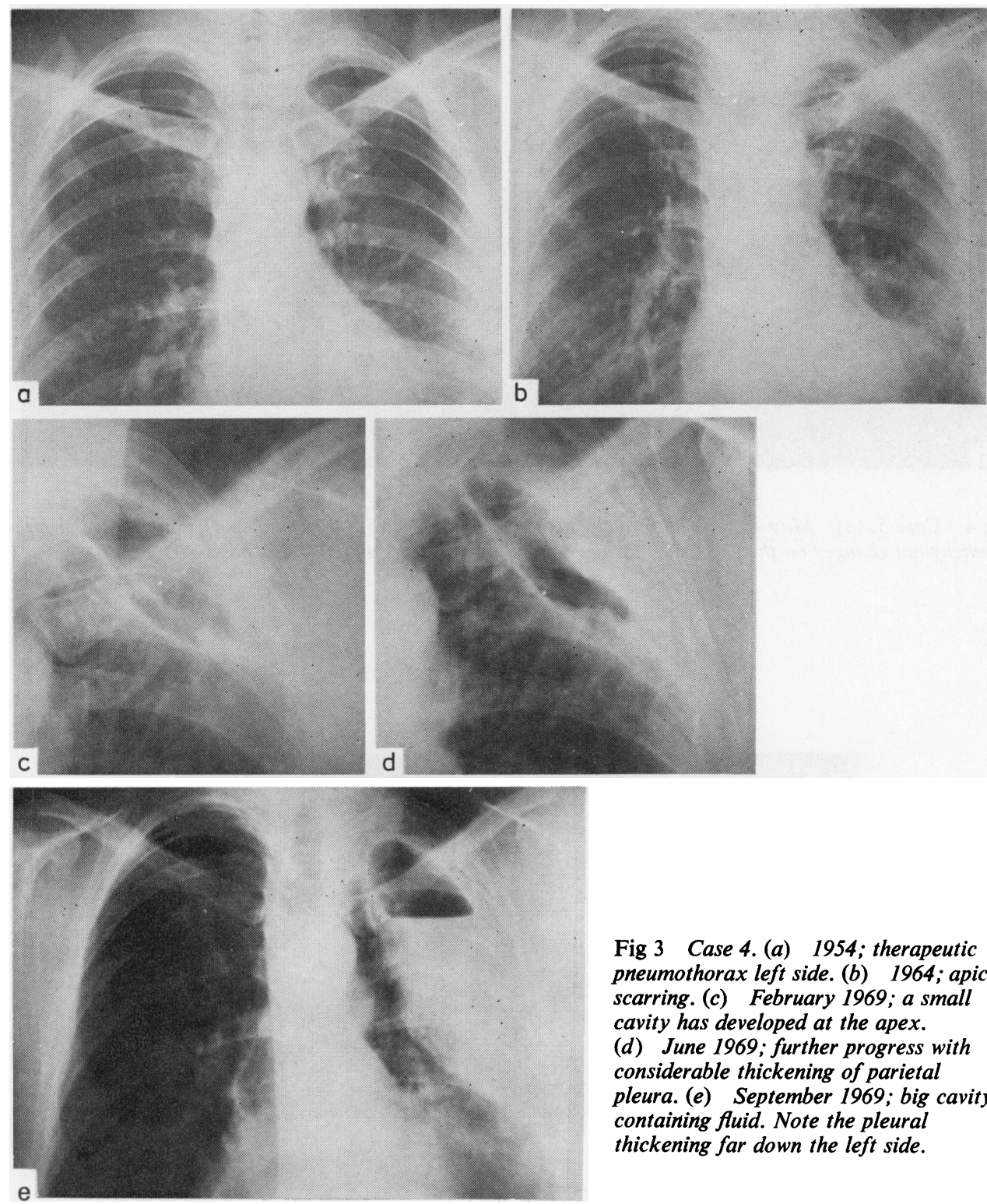

Fig 3 Case 4. (a) 1954; therapeutic pneumothorax left side. (b) 1964; apical scarring. (c) February 1969; a small cavity has developed at the apex.

(d) June 1969; further progress with considerable thickening of parietal pleura. (e) September 1969; big cavity containing fluid. Note the pleural thickening far down the left side.

vasion rather than the antigen-antibody reaction suggested by the authors. 1011

There are a number of reports of cases with pleural aspergillosis, many of which might well be caused by fungal pleural invasion rather than superinfection of an empyema caused by some other agent. ${ }^{6} 712-20$

Invasive pleural aspergillosis is potentially fatal, and the treatment of choice seems to be decortica- tion. This should be done early to avoid progressive deterioration of the patient's general condition and destruction of the lung, which would then necessitate pneumonectomy. Early operation will probably also reduce the risk of postoperative aspergillus empyema. To reduce this risk further, preoperative systemic (and if possible local) treatment with antifungal agents should be given.

In inoperable patients, local treatment with anti- 

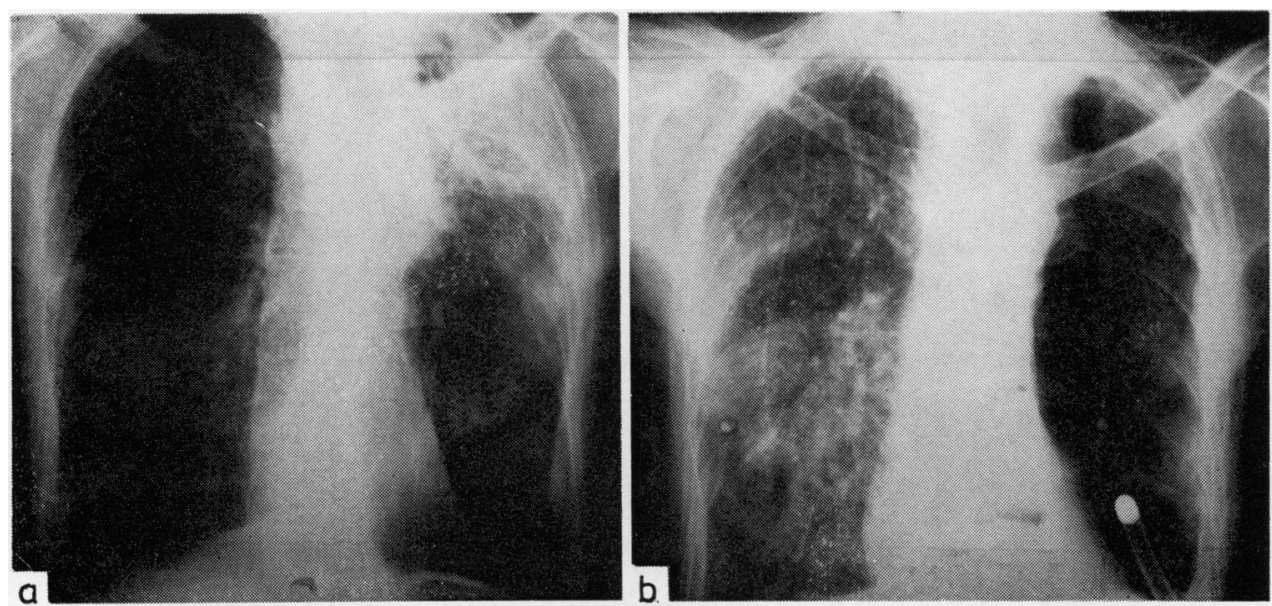

Fig 4 Case 5. (a) May 1979; widespread changes at left apex. (b) After left pneumonectomy: progressive parenchymal changes on the right side. At necropsy aspergillus pneumonia was found.

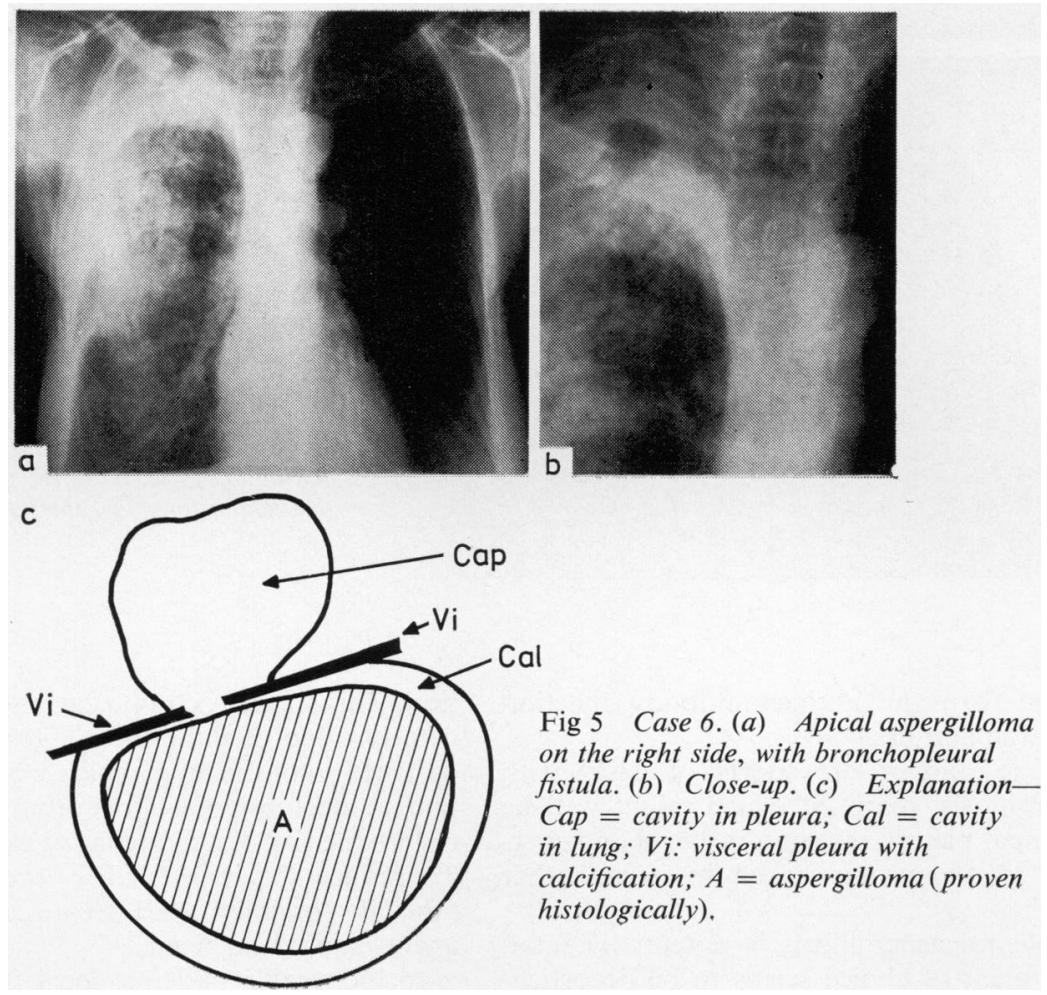

Fig 5 Case 6. (a) Apical aspergilloma on the right side, with bronchopleural fistula. (b) Close-up. (c) ExplanationCap $=$ cavity in pleura $;$ Cal = cavity in lung; Vi: visceral pleura with calcification; $A=$ aspergilloma (proven histologically). 
fungal drugs has been reported to give good results in aspergillus empyema, ${ }^{6} 7$ but as seen from cases 2 and 5 , this will not always lead to cure. This is understandable in view of the thick fibrous tissue in which the fungus grows-penetration of drugs therein must be very slow.

Aspergillus pneumonia, as occurred in case 5 , is very rare in patients without a malignant condition or not having immunosuppressive treatment. The poor general condition of the patient because of the long-standing empyema was probably a predisposing factor. Antifungal treatment was of no avail.

\section{References}

${ }^{1}$ Research Committee of the British Tuberculosis Association. Aspergillus in persistent lung cavities after tuberculosis. Tubercle 1968;49:1-13.

${ }^{2}$ Henderson AH, English MP, Vecht RJ. Pulmonary aspergillosis. A survey of its occurrence in patients with chronic lung disease and a discussion of the significance of diagnostic tests. Thorax $1968 ; 23: 513-8$.

${ }^{3}$ Turner-Warwick M. Aspergillus fumigatus and lung disease. Postgrad Med J 1979;55:642-4.

${ }^{4}$ Davies D, Somner AR. Pulmonary aspergillomas treated with corticosteroids. Thorax 1972;27:156-62.

${ }^{5}$ Libschitz HI, Atkinson GW, Israel HL. Pleural thickening as a manifestation of aspergillus superinfection. $A m ~ J$ Radiol Radiother Nucl 1974;120:883-6.

- Voisin C, Sergeant YH, Macquet V, Wallaert C, Wattel F, Salomon JL. L'aspergillose pleurale. Aspects étiologiques, anatomo-cliniques et thérapeutiques. A propos de 15 observations. Rev Tuberc Pneumonol 1969;33:477-86.
${ }^{7}$ Krákowka P, Rowinska E, Halweg H. Infection of the pleura by aspergillus fumigatus. Thorax $1970 ; 25: 245-53$.

Meredith HC, Cogan BM, McLaulin B. Pleural aspergillosis. Am J Roentgenol 1978;130:164-6.

9 Katz AS, Weiss W, Steinberg A. The migrating mycetoma. Br J Dis Chest 1977;71:289-94.

${ }_{10}$ Hilvering C, Stevens EAM, Orie NGM. Fever in aspergillus mycetoma. Thorax 1970;25:19-24.

${ }^{11}$ Stevens EAM, Hilvering C, Orie NGM. Inhalation experiments with extracts of Aspergillus fumigatus on patients with allergic aspergillosis and aspergilloma. Thorax 1970;25:11-18.

12 Orie NGM, de Vries GA, Kikstra A. Growth of aspergillus in the human lung. Am Rev Respir Dis 1960;82:649-62.

18 Fréour P, Laumonier P, Carré JC, Potaux L, Morvan A. Sur un volumineux aspergillome intra-pleural. J Franc Med Chir Thorac 1963;17:419-25.

14 Fourchon J, Lancestre G. Aspergillome pleural. J Franc Med Chir Thorac 1964;18:679-88.

${ }^{16}$ Monod O, Dieudonné P, Tardieu P. Les aspergilloses pulmonaires post-operatoires. J Franc Med Chir Thorac 1964;18:579-90.

16 Tardieu P, Dieudonné P, Monod O, Atchoarena JB. Aspergillomes pleuraux. J Franc Med Chir Thorac 1964; 18:591-6.

17 Pesle GD, Hummel J, Triboulet F. Aspergillose pleurale. Rev Tuberc Pneumol (Paris) 1967;31:1079-82.

18 Bariéty M, Poulet J, Almosni M. Aspergillose pleurale survenue douze ans aprés une aspergillose pulmonaire traitée par lobectomie. J Franc Med Chir Thorac 1969; 23:137-46.

19 Herring M, Pecora D. Pleural aspergillosis: a case report. Am Surg 1976;42:300-2.

${ }^{20}$ Sors C, Gonnot G, Toty L. Aspergillose pleurale. A propos d'un cas d'aspergillome pleural géant. Rev Franc Mal Respir 1979;7:66-8. 